\title{
Celecoxib Inhibits Serum Amyloid A-Induced Matrix Metalloproteinase-10 Expression in Human Endothelial Cells
}

\author{
Yulan Zhao Shuli Zhou Chew-Kiat Heng \\ Department of Pediatrics, Yong Loo Lin School of Medicine, National University of Singapore, Singapore
}

\section{Key Words}

Celecoxib $\cdot$ COX-2 $\cdot$ Cyclooxygenases $\cdot$ Matrix metalloproteinases $\cdot M M P-10 \cdot$ Prostaglandin $E_{2} \cdot$ Serum amyloid $A$

\begin{abstract}
Background: Although serum amyloid A (SAA) is an established biomarker of coronary artery disease (CAD), its direct role in matrix degradation is obscure. This study investigated the effect of SAA on the expression of matrix metalloproteinase-10 (MMP-10) in endothelial cells. The effect of celecoxib on SAA-dependent MMP-10 expression and its possible mediator were also investigated. Methods and Results: From our time course microarray screening, SAA $(20 \mu \mathrm{g} / \mathrm{ml})$ was found to increase MMP-10 mRNA expression over time (4-48 h) in human endothelial cells. Quantitative real-time PCR confirmed this transcriptional induction. Correspondingly, secreted MMP-10 protein was also markedly induced by SAA treatment for $24 \mathrm{~h}$ in a dose-dependent manner. We further examined cyclooxygenase-2 (COX-2) and its major product, prostaglandin $\mathrm{E}_{2}\left(\mathrm{PGE}_{2}\right)$, as possible mediators of MMP-10 induction. Direct $\mathrm{PGE}_{2}$ treatment could result in MMP-10 induction. Celecoxib, a selective COX-2 inhibitor, suppressed MMP-10 secretion induced by SAA. Conclusions: SAA induced MMP-10 expression and celecoxib prevented its induction. MMP-10 induction was at least partly mediated by $\mathrm{PGE}_{2}$.

Copyright $\odot 2008$ S. Karger AG, Basel
\end{abstract}

\section{Introduction}

Serum amyloid A (SAA) is a major acute-phase protein. Since its concentrations increase 100- to 1,000-fold in response to inflammatory stimuli, it has been shown to be a useful biomarker of inflammation [1]. Elevated circulating SAA levels were found in patients with unstable angina and acute myocardial infarction (AMI) [2]. It has been reported as a significant predictor of the risk of coronary artery disease (CAD) [3]. Although SAA is normally produced in the liver, it is also expressed in human atherosclerotic lesions [4], and expression was increased at the site of ruptured plaques in AMI [5], suggesting that SAA may play a direct role in CAD. Recent studies have demonstrated that SAA may significantly increase the expression of cellular adhesion molecules [6] and cytokines [7] in cultured endothelial cells, which are markers for the initiation of atherosclerosis. Very recently, SAA was also found to induce tissue factor and inhibit tissue factor pathway inhibitor, thus leading to precoagulation [8]. However, possible effects of SAA on other stages of atherogenesis remain obscure.

Matrix metalloproteinases (MMPs) are a family of zinc-dependent endopeptidases capable of degrading extracellular matrix (ECM) components, e.g. collagens, laminin, fibronectin and other glycoproteins [9]. A broader spectrum and/or higher level of MMP activation, especially when associated with inflammation,

\section{KARGER}

Fax +41613061234 E-Mail karger@karger.ch www.karger.com
Dr. Chew-Kiat Heng

Department of Pediatrics, Yong Loo Lin School of Medicine

Cardiovascular Genetics Lab, National University of Singapore

Singapore 119074 (Singapore)

Tel. +65 6772 5708, Fax +65 6774 2796, E-Mail paehck@nus.edu.sg 
could lead to pathological matrix destruction and plaque rupture, which eventually promotes coronary thrombosis and AMI [10]. MMPs are regulated by soluble cytokines and cell-cell interaction. Proinflammatory cytokines, such as tumor necrosis factor- $\alpha(\mathrm{TNF} \alpha)$ and interleukin-1 $\beta$ (IL-1 $\beta$ ), could induce MMPs in both smooth muscle cells [11] and endothelial cells (ECs) [12]. Recently, C-reactive protein (CRP) was also reported to induce MMP-1 and -10 in ECs. Increased CRP and MMP-10 colocalized in the endothelial layer and macrophage-rich areas in advanced atherosclerosis [13]. As induced MMPs are usually associated with inflammation, it would be interesting to examine the effect of anti-inflammatory therapy on MMPs. One common anti-inflammatory therapy is to selectively inhibit cycooxygenase-2 (COX-2) activity and its major product prostaglandin $\mathrm{E}_{2}\left(\mathrm{PGE}_{2}\right)$. Some studies also found that production of several MMPs (MMP-2 and -9) in atheromas was associated with inducible COX-2 and mediated via a $\mathrm{PGE}_{2}$-dependent pathway $[14,15]$. Hence a widely used COX-2 inhibitor, celecoxib, may effectively prevent MMP induction beyond its anti-inflammatory function. Although the primary effect of celecoxib on CAD remains a matter of debate, some researchers recently reported that celecoxib treatment could have protective effects. Celecoxib has been shown to significantly decrease monocyte chemoattractant protein-1 (MCP-1) expression, macrophage infiltration [16], and TNF $\alpha$-induced tissue factor expression and activity [17]. Recently, celecoxib was reported to suppress MMP-1, -2 and -9 secretion induced by cytokines (TNF $\alpha$ and IL-1 $\beta$ ) [18]. However, its effect on other MMPs remains unknown.

In this study, we found that SAA could induce endothelial MMP-10 expression and that celecoxib could prevent such induction, which was at least partly mediated by $\mathrm{PGE}_{2}$.

\section{Materials and Methods}

\section{Cell Culture}

Primary human umbilical vein endothelial cells (HUVECs, Clonetics) and human coronary artery endothelial cells (HCAECs, Clonetics) were cultured in EGM-2MV medium (Clonetics) with full supplements and 5\% FBS. The medium was exchanged every other day until the cells reached $90 \%$ confluence. Cells were then trypsinized and reseeded. HUVECs from passages 4-5 and HCAECs from passages 3-4 were used in all of the following experiments.

In SAA treatment studies, cells were cultured to confluence and SAA (PeproTech) was added to the medium at concentrations of $0-20 \mu \mathrm{g} / \mathrm{ml}$ for $4-48 \mathrm{~h}$. The normal SAA level is considered to be less than $0.1 \mu \mathrm{M}$ or $1.25 \mu \mathrm{g} / \mathrm{ml}$. Under inflammatory conditions, the maximal levels could be up to $80 \mu \mathrm{M}$ or $1 \mathrm{mg} / \mathrm{ml}$ [1]. The concentrations of SAA $(1-20 \mu \mathrm{g} / \mathrm{ml})$ tested were within the range that represented low-grade inflammation, a level which has been shown to put an individual at risk of CAD by many clinical studies $[2,3]$. Endotoxin levels of $\leq 1$ endotoxin unit/ $\mu$ g protein in SAA preparation were confirmed by the E-TOXATE test kit (Sigma-Aldrich). In the COX-2 inhibitor study, cells were pretreated with $10 \mu \mathrm{M}$ of celecoxib (Celebrex ${ }^{\mathrm{TM}}$, Pfizer) [16] for $1 \mathrm{~h}$ and then treated with SAA $20 \mu \mathrm{g} / \mathrm{ml}$ for $24 \mathrm{~h}$. To study PGE 2 , cells were incubated with $\mathrm{PGE}_{2}$ (Sigma-Aldrich) at a concentration of 0.01$1 \mu \mathrm{M}$ for $24 \mathrm{~h}$ since $0.1 \mu \mathrm{M}$ is the effective concentration reported in other studies $[13,14]$.

\section{Affymetrix Microarray Analysis}

To determine HUVEC gene transcript profiles in the 4 different groups, relative abundance of mRNAs in SAA (4, 24 and $48 \mathrm{~h}$ ) groups were compared with the control group using the Human Genome U133 Plus 2.0 Array (HG-U133 Plus 2.0, Affymetrix) containing probes for about 39,000 known human genes. Each group had 2 individual samples and each sample was applied onto one GeneChip. Total RNA was isolated from fresh endothelial samples using the RNeasy Mini Kit (Qiagen). In accordance with the Affymetrix protocol, $2 \mu \mathrm{g}$ of purified total RNA were reverse transcribed to cDNA and transcribed to biotinylated cRNA. The labeled cRNA was fragmented, mixed into hybridization cocktail, injected into the GeneChip HG-U 133 Plus 2.0 cartridge and incubated at $45^{\circ} \mathrm{C}$ for $16 \mathrm{~h}$. The arrays were washed, stained and finally scanned using the Affymetrix GeneChip ${ }^{\circledR}$ Scanner 3000. The quality of the fragmented biotin-labeled cRNA was ascertained using Test-3 arrays.

Affymetrix Microarray Suite version 5.0 was used to analyze the scanned image. Expression patterns for each duplicated SAA sample $(4,24$ and 48) were compared to each duplicated control sample. Hence, each time point had 4 sample comparisons. The robust 'increase' (I) and 'decrease' (D) was defined by Affymetrix as genes flagged with signal $\log _{2}$ ratio not less than 1.0 and those flagged with signal $\log _{2}$ ratio not more than -1.0 , respectively. If a gene was robustly increased or decreased in all 4 individual sample comparisons, it was labeled as 'I' or 'D', respectively, in the gene list table, which presents the mean value of the signal log ratio of the 4 sample comparisons. Others were labeled as ' $\mathrm{NC}$ ' which meant 'no change'. The complete signal intensity data were uploaded onto Gene Expression Omnibus with the access number GSE6241.

\section{Gene Expression Level Determination by Quantitative}

Real-Time PCR (QRT-PCR)

After SAA $(20 \mu \mathrm{g} / \mathrm{ml})$ treatments at various durations $(4,24$ and $48 \mathrm{~h}$ ), total RNA was isolated using RNAeasy Mini Kits (Qiagen). The LightCycler ${ }^{\circledR}$ RNA Master SYBR Green I kits (Roche) were used to quantify the starting mRNA of MMP-10 and COX-2. The housekeeping gene glyceraldehyde-3-phosphate dehydrogenase was used as an internal control. Primer sequences could be provided on request. Following the manufacturer's manual, $90 \mathrm{ng}$ RNA template, primers, $\mathrm{Mn}(\mathrm{OAc})_{2}$ and LightCycler RNA Master SYBR Green I were mixed well and transferred to LightCycler capillaries. The program of the LightCycler 2.0 system was set up to carry out reverse transcription, denaturation, amplification, melting curve analysis and final cooling. The crossing point of 
each sample was measured and the relative treatment versus control ratio of each target gene was analyzed with LightCycler software version 3.5.

\section{SDS-PAGE and Western Blotting}

Thirty micrograms of total protein samples were loaded and separated by $12 \%$ SDS-PAGE gel. After $2 \mathrm{~h}$ of electrotransfer at $90 \mathrm{~V}$, the nitrocellulose membranes were blocked for $1 \mathrm{~h}$ with $5 \%$ nonfat dry milk and $0.1 \%$ Tween-20 in Tris-buffered saline. The membrane was incubated with mouse monoclonal anti-COX-2 antibody (1:1,000; Caymen) overnight at $4^{\circ} \mathrm{C}$. After washing, the membranes were incubated with diluted anti-mouse secondary antibody (1:2,000; Cell Signaling) for $1 \mathrm{~h}$ at room temperature. After thorough washing, the blots were developed with the LumiGLO substrate (Cell Signaling) for $1 \mathrm{~min}$ and exposed to Clear Blue X-ray film (Pierce). For MMP-10 determination, $10 \mu \mathrm{l}$ of conditioned culture medium samples were separated by $12 \%$ SDS-PAGE gene and blotted at $90 \mathrm{~V}$ for $1 \mathrm{~h}$. Primary rabbit polyclonal anti-MMP-10 antibody (Affinity Bioreagents) was used at a concentration of 1:2,000 and that of anti-rabbit secondary antibody (Cell Signaling) at 1:2,000. Bands were quantified by densitometry using a scanner and the Multianalyst software (Bio-Rad). The signals were normalized with $\beta$-actin. Evenness of sample loading was confirmed by Ponceau $\mathrm{S}$ staining.

\section{MMP-10 Determination by ELISA}

Cells of equal density (10,000 cells/well) were seeded onto 96well plates. After an overnight incubation, they were stimulated with $0-20 \mu \mathrm{g} / \mathrm{ml} \mathrm{SAA}$ or $0-1 \mu \mathrm{M} \mathrm{PGE}$ for $24 \mathrm{~h}$. The culture supernatants were collected and MMP-10 levels were determined using the Quantikine ELISA kit (R\&D Systems). Twenty microliters of the culture medium were diluted with $30 \mu \mathrm{l}$ of calibrator diluents and $100 \mu \mathrm{l}$ of assay diluents and then added to a primary antibody-coated plate and incubated for $2 \mathrm{~h}$ at room temperature with shaking. After washing, $200 \mu \mathrm{l}$ of MMP-10 conjugate were added to each well and incubated for $2 \mathrm{~h}$ at room temperature. Following thorough washing, $200 \mu \mathrm{l}$ of substrate solution were added and incubated in the dark for $30 \mathrm{~min}$ for color development. The protein concentration was determined by the absorbance at 450/540 $\mathrm{nm}$ after adding stop solution.

\section{$P_{G} E_{2}$ Expression Determined by EIA}

The level of $\mathrm{PGE}_{2}$, the primary product of COX-2, was assessed using a commercial EIA kit (Caymen). Briefly, $50 \mu \mathrm{l}$ of conditioned medium were incubated with $50 \mu \mathrm{l}$ of $\mathrm{PGE}_{2}$ AChE tracer and $50 \mu \mathrm{l}$ of monoclonal antibody at $4^{\circ} \mathrm{C}$ for $18 \mathrm{~h}$. After thorough washing, $200 \mu \mathrm{l}$ of Ellman's reagent were added to each well and incubated in the dark for $75 \mathrm{~min}$. Absorbance was measured at $410 \mathrm{~nm}$ by a microplate reader (Sunrise).

\section{Statistical Analysis}

Measurements were expressed as means \pm SD from at least 3 independent experiments. The differences were compared by Student's t test with Bonferroni correction using Microsoft Excel. A significant difference was defined as $\mathrm{p}<0.05 /$ number of comparisons.
Table 1. Microarray results for MMPs and tissue inhibitors of metalloproteinase in HUVECs

\begin{tabular}{|c|c|c|c|c|c|c|}
\hline \multirow{2}{*}{\multicolumn{2}{|c|}{ Gene }} & \multicolumn{5}{|c|}{ SAA $(20 \mu \mathrm{g} / \mathrm{ml})$ treatment } \\
\hline & & $4 \mathrm{~h}$ & & $24 \mathrm{~h}$ & & $48 \mathrm{~h}$ \\
\hline MMP-1 & & $\mathrm{NC}$ & & $\mathrm{NC}$ & & $\mathrm{NC}$ \\
\hline MMP-2 & & $\mathrm{NC}$ & & NC & & $\mathrm{NC}$ \\
\hline MMP-3 & & $\mathrm{NC}$ & & $\mathrm{NC}$ & & $\mathrm{NC}$ \\
\hline MMP-7 & & $\mathrm{NC}$ & & $\mathrm{NC}$ & & $\mathrm{NC}$ \\
\hline MMP-8 & & $\mathrm{NC}$ & & $\mathrm{NC}$ & & $\mathrm{NC}$ \\
\hline MMP-9 & & $\mathrm{NC}$ & & $\mathrm{NC}$ & & $\mathrm{NC}$ \\
\hline MMP-10 & & +3.3 & & +3.7 & & +3.2 \\
\hline MMP-11 & & $\mathrm{NC}$ & & $\mathrm{NC}$ & & $\mathrm{NC}$ \\
\hline MMP-12 & & $\mathrm{NC}$ & & $\mathrm{NC}$ & & $\mathrm{NC}$ \\
\hline MMP-13 & & $\mathrm{NC}$ & & $\mathrm{NC}$ & & $\mathrm{NC}$ \\
\hline MMP-14 & & $\mathrm{NC}$ & & $\mathrm{NC}$ & & $\mathrm{NC}$ \\
\hline MMP-15 & & $\mathrm{NC}$ & & $\mathrm{NC}$ & & $\mathrm{NC}$ \\
\hline MMP-16 & & $\mathrm{NC}$ & & $\mathrm{NC}$ & & $\mathrm{NC}$ \\
\hline MMP-17 & & $\mathrm{NC}$ & & $\mathrm{NC}$ & & $\mathrm{NC}$ \\
\hline MMP-18 & & $\mathrm{NC}$ & & $\mathrm{NC}$ & & $\mathrm{NC}$ \\
\hline MMP-19 & & $\mathrm{NC}$ & & $\mathrm{NC}$ & & +2.3 \\
\hline MMP-20 & & $\mathrm{NC}$ & & $\mathrm{NC}$ & & NC \\
\hline MMP-21 & & $\mathrm{NC}$ & & $\mathrm{NC}$ & & $\mathrm{NC}$ \\
\hline MMP-23 & & $\mathrm{NC}$ & & $\mathrm{NC}$ & & $\mathrm{NC}$ \\
\hline MMP-24 & & $\mathrm{NC}$ & & $\mathrm{NC}$ & & $\mathrm{NC}$ \\
\hline MMP-25 & & $\mathrm{NC}$ & & $\mathrm{NC}$ & & $\mathrm{NC}$ \\
\hline MMP-26 & & $\mathrm{NC}$ & & $\mathrm{NC}$ & & $\mathrm{NC}$ \\
\hline MMP-27 & & $\mathrm{NC}$ & & $\mathrm{NC}$ & & $\mathrm{NC}$ \\
\hline MMP-28 & & $\mathrm{NC}$ & & $\mathrm{NC}$ & & $\mathrm{NC}$ \\
\hline TIMP-1 & & $\mathrm{NC}$ & & $\mathrm{NC}$ & & $\mathrm{NC}$ \\
\hline TIMP-2 & & $\mathrm{NC}$ & & $\mathrm{NC}$ & & $\mathrm{NC}$ \\
\hline TIMP-3 & & $\mathrm{NC}$ & & $\mathrm{NC}$ & & $\mathrm{NC}$ \\
\hline TIMP-4 & & $\mathrm{NC}$ & & $\mathrm{NC}$ & & $\mathrm{NC}$ \\
\hline COX-1 & & $\mathrm{NC}$ & & $\mathrm{NC}$ & & $\mathrm{NC}$ \\
\hline COX-2 & +5.0 & I & +3.4 & I & +2.6 & I \\
\hline
\end{tabular}

Data represent the mean signal $\log _{2}$ ratio to control. $\mathrm{NC}=\mathrm{No}$ change; $\mathrm{I}=$ increase.

\section{Results}

Transcriptional Profiling of MMPs, Tissue Inhibitors of Metalloproteinase and COXs

To monitor the potential effects of SAA on endothelial cells, a time course microarray investigation was carried out. We focused on the genes involved in vascular proteolysis, one of the preceding events that may lead to AMI. These genes include MMPs, tissue inhibitors of metalloproteinase and their possible COX regulators. SAA highly induced MMP-10 expression from the 4 th $\mathrm{h}$, and the effect was sustained over the 48-hour period of our experiment (table 1), while MMP-19 was only induced at $48 \mathrm{~h}$. The ab- 

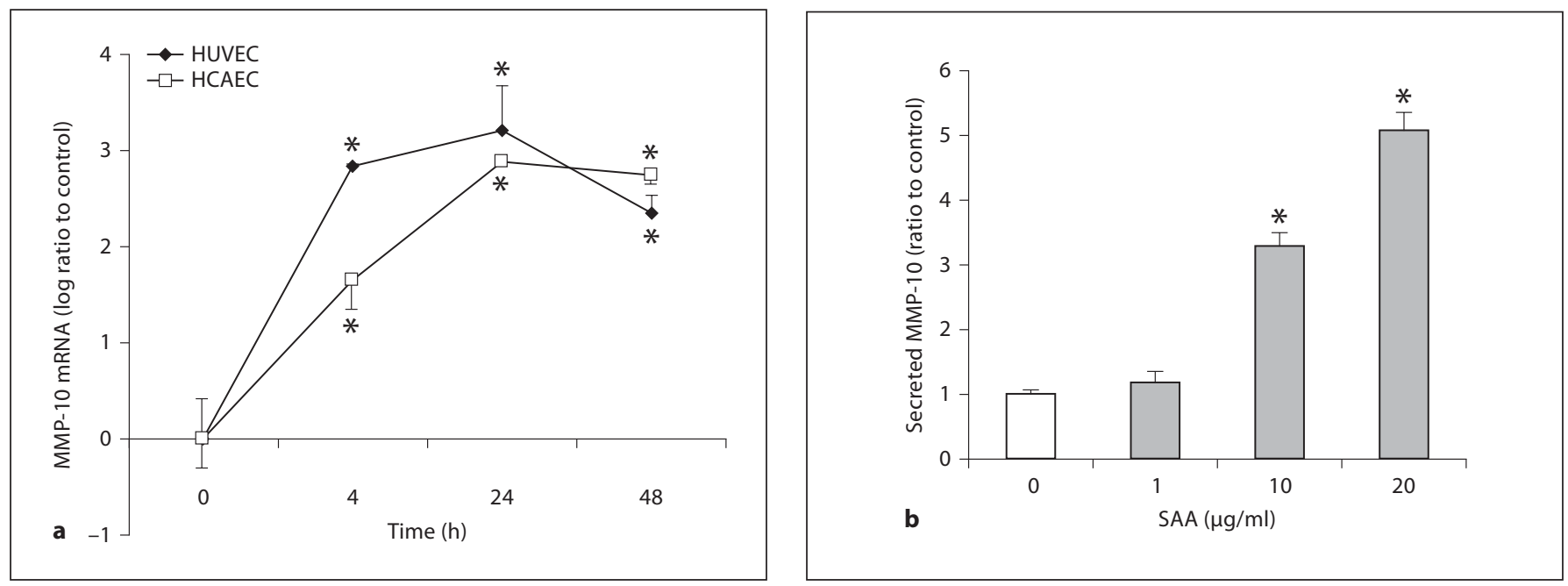

Fig. 1. SAA-induced MMP-10 transcription, secretion and activation in HUVECs $(\mathbf{a}-\mathbf{c})$ and HCAECs $(\mathbf{a})$. A representative blot is shown in (c). In non-time course studies, cells were treated for $24 \mathrm{~h} .{ }^{*} \mathrm{p}<0.05$ vs. control. $\mathrm{n}=4$ for control and SAA 24 -hour groups and $\mathrm{n}=3$ for all other groups. Unless otherwise indicated, HUVECs were incubated with $20 \mu \mathrm{g} / \mathrm{ml} \mathrm{SAA}$ for $24 \mathrm{~h}$.

solute expression level of MMP-19 was much lower than that of MMP-10 (data not shown). SAA had no effects on tissue inhibitors of metalloproteinase and other MMPs. We therefore selected MMP-10 for further study. SAA was also found to selectively induce COX-2 but not COX-1.

\section{SAA Induces MMP-10 Expression in HUVECs and} HCAECs

To examine the effects of SAA on endothelial MMP-10 expression, QRT-PCR, ELISA and Western blots were

carried out to measure MMP-10 at both the mRNA and protein levels. Figure 1a shows that SAA induced MMP10 gene transcription from 4 to $48 \mathrm{~h}$ in both HUVECs and HCAECs. The data from QRT-PCR were consistent with those obtained from microarrays. Total MMP-10 protein secretion in conditioned medium was also induced by SAA incubation in a concentration-dependent manner using the 24-hour time point (fig. 1b). SAA was shown to be effective at a concentration of $10 \mu \mathrm{g} / \mathrm{ml}$. Moreover, SAA induced both zymogen $(56 \mathrm{kDa})$ and ac- 


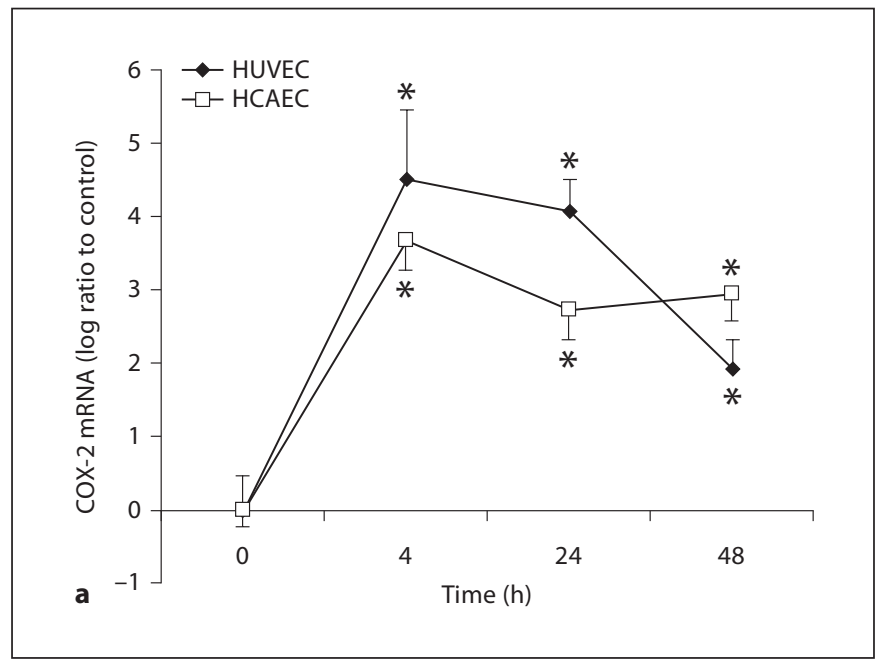

Fig. 2. SAA-induced COX-2 expression (a, b) and $\mathrm{PGE}_{2}$ production (c). $\mathbf{c} \mathrm{PGE}_{2}$ production was induced by SAA and inhibited by celecoxib. HUVECs were pretreated with celecoxib $(10 \mu \mathrm{M})$ for $1 \mathrm{~h}$ before SAA treatment. Unless otherwise indicated, HUVECs were incubated with $20 \mu \mathrm{g} / \mathrm{ml}$ SAA for $24 \mathrm{~h} .{ }^{*} \mathrm{p}<0.05 \mathrm{vs}$. control and celecoxib, respectively. $\mathrm{n}=4$ for control and SAA 24-hour groups and $n=3$ for all other groups.

tive form (46 kDa) of MMP-10 (fig. 1c). In HCAECs, MMP-10 production was similarly induced by SAA treatment after $24 \mathrm{~h}$ (data not shown).

\section{SAA Induces COX-2 Expression and $P G E_{2}$ Production}

To find the possible mediator of MMP-10 induction, we further examined the COX-2 pathway. COX-2 mRNA levels were markedly induced by SAA treatment over time with a peak at $4 \mathrm{~h}$ (fig. $2 \mathrm{a}$ ). Its protein expression was correspondingly induced (fig. $2 \mathrm{~b}$ ). $\mathrm{PGE}_{2}$ is the primary COX-2 product of arachidonic acid and its activity influences inflammation, immune modulation and vascular integrity. Figure $2 \mathrm{c}$ shows that SAA significantly elevated $\mathrm{PGE}_{2}$ production and that pretreatment with celecoxib $(10 \mu \mathrm{M})$ could effectively suppress the SAA-induced $\mathrm{PGE}_{2}$ production. This confirmed celecoxib as an effective anti-inflammatory drug.

\section{$P G E_{2}$ Induces MMP-10 Expression}

Subsequently, we determined whether $\mathrm{PGE}_{2}$ could directly induce MMP-10 expression. Our results showed

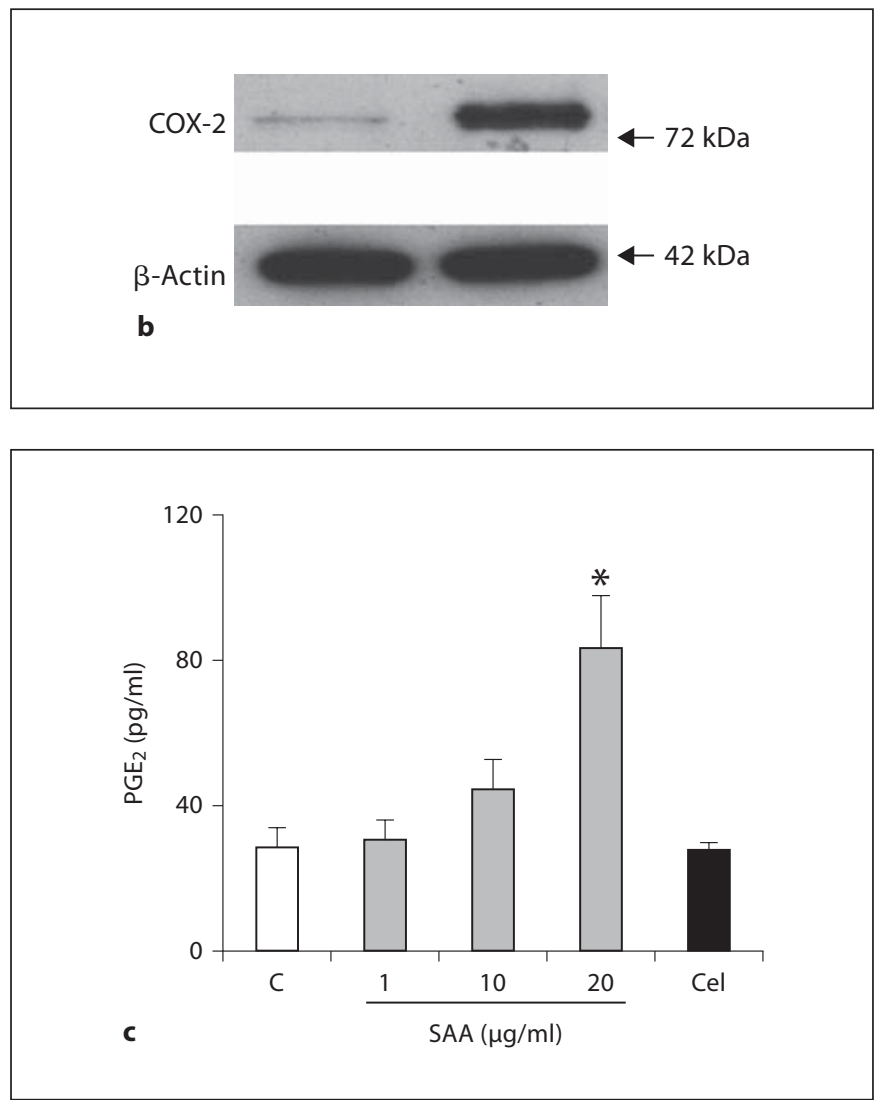

that the addition of $0.1-1 \mu \mathrm{M} \mathrm{PGE}_{2}$ in culture medium could upregulate both transcription and secretion of MMP-10 (fig. 3), suggesting that the effect of SAA on MMP-10 induction is probably mediated through $\mathrm{PGE}_{2}$.

\section{Celecoxib Inhibits SAA-Dependent MMP-10 \\ Induction}

Based on the findings that SAA could induce MMP10 , at least partly, through $\mathrm{PGE}_{2}$, and that celecoxib could block $\mathrm{PGE}_{2}$ production, we next measured MMP-10 expression levels in both HUVECs and HCAECs in another set of experiments to test the effect of celecoxib pretreatment on SAA-dependent MMP-10 production. The SAA-induced MMP-10 secretion in conditioned medium was significantly suppressed by celecoxib preincubation in both ECs (fig. 4a). Furthermore, both the proactive and active form of MMP-10 was inhibited by celecoxib (fig. 4b). However, celecoxib did not influence the transcription level of MMP-10 (fig. 4c). Interestingly, celecoxib also inhibited TNF $\alpha$-induced MMP-10 secretion (fig. 4a). 

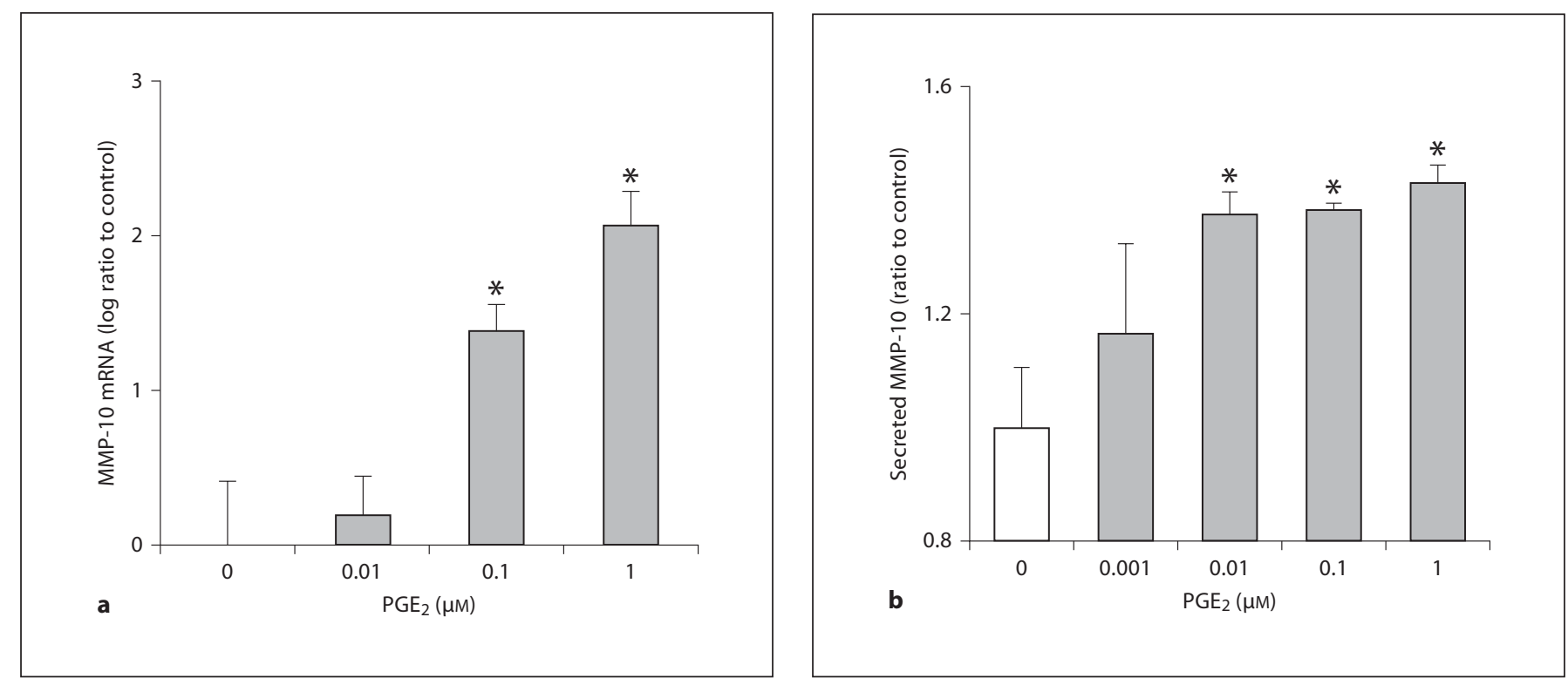

Fig. 3. The effects of $\mathrm{PGE}_{2}$ on MMP-10 induction at the level of gene transcription (a) and protein secretion (b). Cells were incubated with $\mathrm{PGE}_{2}(0-1 \mu \mathrm{M})$ for 24 h. ${ }^{*} \mathrm{p}<0.05$ vs. control. $\mathrm{n}=3$.

\section{Discussion}

In 1999, Ross [19] proposed that atherosclerosis is an inflammatory disease and that inflammatory factors play key roles in atherogenic processes such as ECM destruction and plaque rupture. Many soluble cytokines have been shown to initiate matrix degradation through MMP induction and activation [20]. Our time course study has shown that SAA could exert a very significant effect on the expression of MMP-10 in human endothelial cells and that the induction could last for at least $48 \mathrm{~h}$. With the addition of $20 \mu \mathrm{g} / \mathrm{ml}$ of SAA to the endothelial cell culture medium, MMP-10 gene transcription and protein production could be markedly increased. Both the precursor and active form of MMP-10 were shown to be elevated. These phenomena have not been reported before in earlier studies involving SAA.

Our results suggested that among MMPs, SAA had a specific effect on the expression of MMP-10 only. MMP10 has not been as well studied as MMP-2, -3 and -9 [21] However, recent studies have demonstrated that MMP-10 is similarly associated with vascular diseases and has important functions like other MMPs. MMP-10 (or stromelysin-2) has a wide substrate repertoire, which includes most of the ECM proteins and proteoglycans except for intact fibrillar collagens [10]. Recently, elevated MMP-10 levels were reported in subjects with higher carotid inti- ma-media thickness [13] and were associated with inflammatory markers (fibrinogen and CRP) [22]. MMP-10 was also reported to activate MMP-1 and accelerate capillary tubular network collapse and regression of collagen matrices in vitro [23]. Another study examined the cardiovascular abnormalities in histone deacetylase $7 \mathrm{mu}-$ tant mice and suggested that their impaired vascular integrity was caused by overexpression of MMP-10 [24]. These findings all pointed to the fact that MMP-10 may contribute to vascular diseases such as atherosclerosis. Although the regulation of MMP-10 remains to be elucidated, some studies revealed that MMP-10 could also be induced by TNF $\alpha$ and ILs [25]. Recently, Montero et al. [13] found that CRP, another acute-phase protein, could induce MMP-10 expression and activity in human ECs. Our study showed that SAA could exert a significant effect on the expression of MMP-10 in both HUVECs and HCAECs, confirming that SAA could have similar effects as other cytokines. Since MMP-10 contributes to ECM degradation, SAA may have another direct role in atherosclerosis beyond merely being proinflammatory.

We subsequently attempted to identify the possible mediator of MMP-10 induction. The inhibitory effect of celecoxib suggested that the $\mathrm{COX}-2 / \mathrm{PGE}_{2}$ pathway may be involved in the regulation of MMP-10 expression. Higher expression of COX-2, PGEs and MMPs were found in symptomatic atherosclerotic lesions, especially 


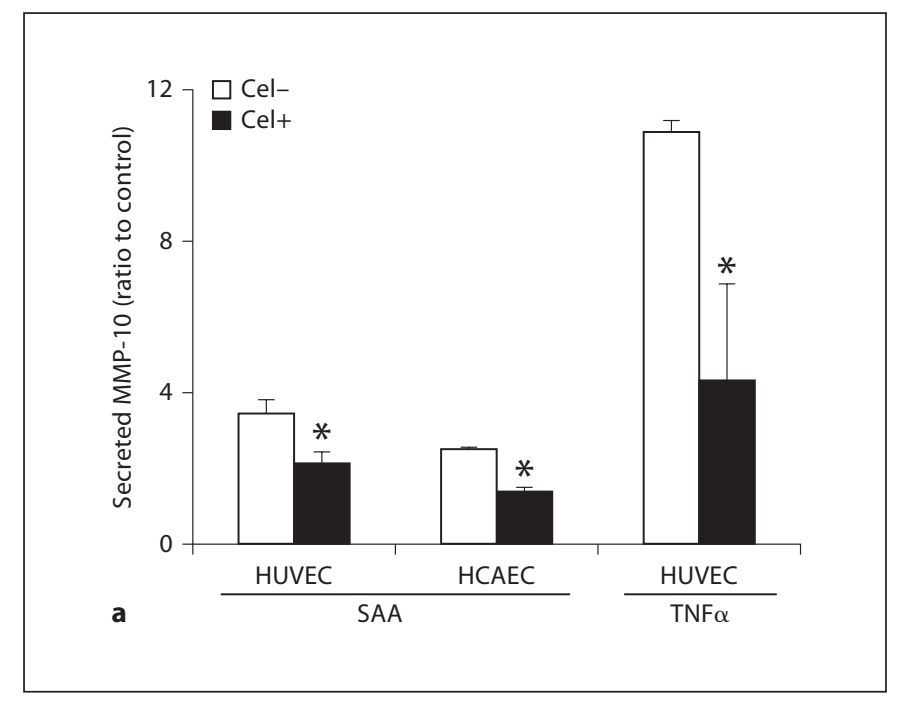

Fig. 4. Celecoxib inhibits the SAA-dependent MMP-10 secretion (a) and activation (b) but not transcription (c). Celecoxib also inhibits TNF $\alpha$-dependent MMP-10 induction (a). HUVECs were used unless otherwise indicated. Cells were pretreated with or without celecoxib $(10 \mu \mathrm{M})$ for $1 \mathrm{~h}$ before SAA $(20 \mu \mathrm{g} / \mathrm{ml})$ treatment or TNF $\alpha(10 \mathrm{ng} / \mathrm{ml})$ treatment for $24 \mathrm{~h}$. The blot is representative of 3 independent blots. ${ }^{*} \mathrm{p}<0.05$ vs. SAA samples. $\mathrm{n}=3-4$; $\mathrm{C}=$ control; $\mathrm{Cel}=$ celecoxib.

at the plaque shoulder [14]. The $-765 \mathrm{G} \rightarrow \mathrm{C}$ polymorphism of the COX-2 gene was reported to have led to a lower expression of COX-2 and MMPs [26]. The same study also found an association of the polymorphism with a decreased risk of myocardial infarction and stroke. In addition, other studies have shown that $\mathrm{PGE}_{2}(0.1 \mu \mathrm{M})$ could directly induce MMP-2 and -9 expression in monocytes [14] and macrophages [15]. In our study, $\mathrm{PGE}_{2}(0.1-$ $1 \mu \mathrm{M})$ treatment could directly induce MMP-10 expression. Our results suggested that the induction of MMP-10 by SAA and TNF $\alpha$ may be mediated through the COX$2 / \mathrm{PGE}_{2}$ pathway.

With increasing evidence of the association between inflammation and atherosclerosis, anti-inflammatory
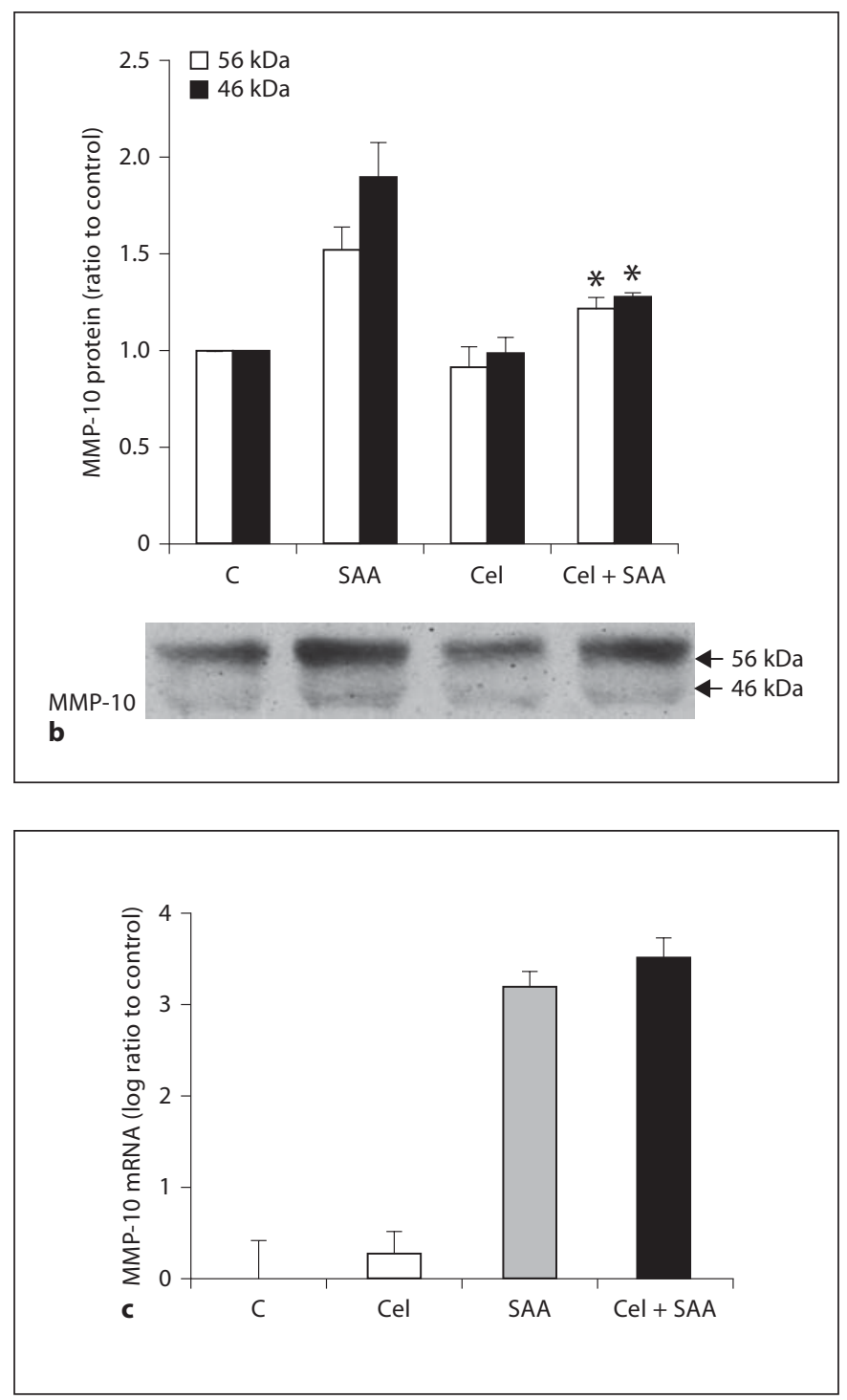

therapy such as COX-2 inhibition has been proposed as a preventive strategy for CAD [27]. However, reports from clinical trials regarding the efficacy and effects of COX-2 inhibitors or coxibs are currently controversial. Some clinical trials had demonstrated that administration of coxibs, such as celecoxib, may lead to an increased cardiovascular risk $[28,29]$. On the other hand, a recent systematic review of observational studies of coxibs suggested that rofecoxib may increase the risk of cardiovascular events, whereas celecoxib does not [30]. Interestingly, celecoxib treatment was found to significantly decrease MCP-1 expression, neointimal hyperplasia and macrophage infiltration in a rabbit atherosclerotic balloon injury model [16]. Some recent in vitro studies also ex- 
amined the pleiotropic effects of celecoxib based on the inflammatory status induced by TNF $\alpha$ or IL- $1 \beta$ stimulation. Steffel et al. [17] demonstrated that $10 \mu \mathrm{M}$ of celecoxib could decrease TNF $\alpha$-induced tissue factor expression and activity in human aortic endothelial cells, whereas rofecoxib and NS-398 had no effects. Since MMPs play a role in atherosclerosis, the effects of celecoxib on MMPs have also been investigated. Celecoxib was reported to suppress the secretion of MMP-1, -2 and -9 , which were induced by cytokines (TNF $\alpha$ and IL-1 $\beta$ ) in rheumatoid fibroblast-like synoviocytes [18]. Our study has demonstrated the proinflammatory effects of SAA in highly inducing COX-2 expression and $\mathrm{PGE}_{2}$ production. Based on the selective COX-2 induction by SAA treatment, we further pretreated ECs with celecoxib $(10 \mu \mathrm{M})$ and its effect was confirmed by the suppressed $\mathrm{PGE}_{2}$ secretion. Since $\mathrm{PGE}_{2}$ was found to directly induce MMP-10 expression, it is logical to observe the inhibitory effects of celecoxib on SAA-induced MMP-10 expression and activation. Similar suppression was also observed in TNF $\alpha$-induced MMP-10 expression. This first study on celecoxib and MMP-10 shows consistent results with previous studies of MCP-1, tissue factor and other MMPs. Therefore, celecoxib may play a beneficial role in preventing matrix degradation and CAD. We speculate that COX-2 inhibition (or $\mathrm{PGE}_{2}$ inhibition) is protective. Other coxibs, such as refocoxib, may have a different mechanism of action, thus increasing the risk of CAD. Another interesting finding from this study is that celecoxib inhibits MMP-10 at the level of protein production but not at transcription, perhaps through its specific effect on factors involved in translation. Alternatively, in the absence of any direct evidence, we may speculate that a feedback mechanism might be involved. At the initial stage, celecoxib may block MMP-10 mRNA and hence subsequent MMP-10 protein production. However, when MMP-10 levels in the cells dropped below a certain threshold level, the feedback mechanism might be initiated to upregulate MMP10 transcription in an attempt to restore homeostasis. In any case, the net effect was a decrease in the protein level, which is more important functionally than at the transcription level.

In summary, the effects of SAA and celecoxib on MMP expression were investigated, and SAA was found to markedly induce MMP-10 expression, whereas celecoxib was found to prevent such induction. The MMP-10 induction was at least partly mediated through $\mathrm{PGE}_{2}$.

\section{Acknowledgments}

This research was generously supported in part by the Human Sciences Program (DSO/DRD/BM/20030260-R3) of the DSO National Laboratories, Singapore. The authors also gratefully acknowledge the excellent technical assistance of Ms. Karen Lee, Ms. Hui-Jen Lye and Mr. Hendrian Sukardi.

\section{References}

1 Malle E, De Beer FC: Human serum amyloid A (SAA) protein: a prominent acute-phase reactant for clinical practice. Eur J Clin Invest 1996;26:427-435.

-2 Liuzzo G, Biasucci LM, Gallimore JR, Grillo RL, Rebuzzi AG, Pepys MB, Maseri A: The prognostic value of C-reactive protein and serum amyloid A protein in severe unstable angina. N Engl J Med 1994;331:417-424.

-3 Johnson BD, Kip KE, Marroquin OC, Ridker PM, Kelsey SF, Shaw LJ, Pepine CJ, Sharaf B, Bairey Merz CN, Sopko G, Olson MB, Reis SE, National Heart, Lung, and Blood Institute: Serum amyloid A as a predictor of coronary artery disease and cardiovascular outcome in women: the National Heart, Lung, and Blood Institute-Sponsored Women's Ischemia Syndrome Evaluation (WISE). Circulation 2004;109:726-732.
4 Meek RL, Urieli-Shoval S, Benditt EP: Expression of apolipoprotein serum amyloid A mRNA in human atherosclerotic lesions and cultured vascular cells: implications for serum amyloid A function. Proc Natl Acad Sci USA 1994;91:3186-3190.

5 Maier W, Altwegg LA, Corti R, Gay S, Hersberger M, Maly FE, Sutsch G, Roffi M, Neidhart M, Eberli FR, Tanner FC, Gobbi S, von Eckardstein A, Luscher TF: Inflammatory markers at the site of ruptured plaque in acute myocardial infarction: locally increased interleukin- 6 and serum amyloid A but decreased C-reactive protein. Circulation 2005;111:1355-1361.

6 Mullan RH, Bresnihan B, Golden-Mason L, Markham T, O’Hara R, FitzGerald O, Veale DJ, Fearon U: Acute-phase serum amyloid A stimulation of angiogenesis, leukocyte recruitment, and matrix degradation in rheumatoid arthritis through an NF- $\kappa$ B-dependent signal transduction pathway. Arthritis Rheum 2006;54:105-114.
7 Yang RZ, Lee MJ, Hu H, Pollin TI, Ryan AS, Nicklas BJ, Snitker S, Horenstein RB, Hull K, Goldberg NH, Goldberg AP, Shuldiner AR, Fried SK, Gong DW: Acute-phase serum amyloid A: an inflammatory adipokine and potential link between obesity and its metabolic complications. PLoS Med 2006;3:e287.

$>8$ Zhao Y, Zhou S, Heng CK: Impact of serum amyloid $\mathrm{A}$ on tissue factor and tissue factor pathway inhibitor expression and activity in endothelial cells. Arterioscler Thromb Vasc Biol 2007;27:1645-1650.

$\longrightarrow 9$ Visse R, Nagase H: Matrix metalloproteinases and tissue inhibitors of metalloproteinases: structure, function, and biochemistry. Circ Res 2003;92:827-839.

10 Newby AC: Dual role of matrix metalloproteinases (matrixins) in intimal thickening and atherosclerotic plaque rupture. Physiol Rev 2005;85:1-31. 
11 Galis ZS, Muszynski M, Sukhova GK, Simon-Morrissey E, Unemori EN, Lark MW, Amento E, Libby P: Cytokine-stimulated human vascular smooth muscle cells synthesize a complement of enzymes required for extracellular matrix digestion. Circ Res 1994;75:181-189.

-12 Hanemaaijer R, Koolwijk P, le Clercq L, de Vree WJ, van Hinsbergh VW: Regulation of matrix metalloproteinase expression in human vein and microvascular endothelial cells. Effects of tumour necrosis factor alpha, interleukin 1 and phorbol ester. Biochem J 1993;296:803-809.

-13 Montero I, Orbe J, Varo N, Beloqui O, Monreal JI, Rodriguez JA, Diez J, Libby P, Paramo JA: C-reactive protein induces matrix metalloproteinase-1 and -10 in human endothelial cells: implications for clinical and subclinical atherosclerosis. J Am Coll Cardiol 2006; 47:1369-1378.

- 14 Cipollone F, Prontera C, Pini B, Marini M, Fazia M, De Cesare D, Iezzi A, Ucchino S, Boccoli G, Saba V, Chiarelli F, Cuccurullo F, Mezzetti A: Overexpression of functionally coupled cyclooxygenase- 2 and prostaglandin E synthase in symptomatic atherosclerotic plaques as a basis of prostaglandin $\mathrm{E}_{2^{-}}$ dependent plaque instability. Circulation 2001;104:921-927.

-15 Cipollone F, Fazia M, Iezzi A, Ciabattoni G, Pini B, Cuccurullo C, Ucchino S, Spigonardo F, De Luca M, Prontera C, Chiarelli F, Cuccurullo F, Mezzetti A: Balance between PGD synthase and PGE synthase is a major determinant of atherosclerotic plaque instability in humans. Arterioscler Thromb Vasc Biol 2004;24:1259-1265.
16 Wang K, Tarakji K, Zhou Z, Zhang M, Forudi F, Zhou X, Koki AT, Smith ME, Keller BT, Topol EJ, Lincoff AM, Penn MS: Celecoxib, a selective cyclooxygenase-2 inhibitor, decreases monocyte chemoattractant protein1 expression and neointimal hyperplasia in the rabbit atherosclerotic balloon injury model. J Cardiovasc Pharmacol 2005;45:6167.

17 Steffel J, Hermann M, Greutert H, Gay S, Luscher TF, Ruschitzka F, Tanner FC: Celecoxib decreases endothelial tissue factor expression through inhibition of c-Jun terminal $\mathrm{NH}_{2}$ kinase phosphorylation. Circulation 2005;111:1685-1689.

18 Cha HS, Ahn KS, Jeon CH, Kim J, Koh EM: Inhibitory effect of cyclo-oxygenase-2 inhibitor on the production of matrix metalloproteinases in rheumatoid fibroblast-like synoviocytes. Rheumatol Int 2004;24:207-211.

19 Ross R: Atherosclerosis - an inflammatory disease. N Engl J Med 1999;340:115-126.

20 Dollery CM, Libby P: Atherosclerosis and proteinase activation. Cardiovasc Res 2006; 69:625-635.

21 Janssens S, Lijnen HR: What has been learned about the cardiovascular effects of matrix metalloproteinases from mouse models? Cardiovasc Res 2006;69:585-594.

22 Orbe J, Montero I, Rodriguez JA, Beloqui O, Roncal C, Paramo JA: Independent association of MMP-10, cardiovascular risk factors and subclinical atherosclerosis. J Thromb Haemost 2007;5:91-97.

23 Saunders WB, Bayless KJ, Davis GE: MMP-1 activation by serine proteases and MMP-10 induces human capillary tubular network collapse and regression in 3D collagen matrices. J Cell Sci 2005; 118:2325-2340.

-24 Chang S, Young BD, Li S, Qi X, Richardson JA, Olson EN: Histone deacetylase 7 maintains vascular integrity by repressing matrix metalloproteinase 10. Cell 2006;126:321334.

25 Van Themsche C, Alain T, Kossakowska AE, Urbanski S, Potworowski EF, St-Pierre Y Stromelysin-2 (matrix metalloproteinase 10) is inducible in lymphoma cells and accelerates the growth of lymphoid tumors in vivo. J Immunol 2004;173:3605-3611.
26 Cipollone F, Toniato E, Martinotti S, Fazia M, Iezzi A, Cuccurullo C, Pini B, Ursi S, Vitullo G, Averna M, Arca M, Montali A, Campagna F, Ucchino S, Spigonardo F, Taddei S, Virdis A, Ciabattoni G, Notarbartolo A, Cuccurullo F, Mezzetti A, Identification of New Elements of Plaque Stability (INES) Study Group: A polymorphism in the cyclooxygenase 2 gene as an inherited protective factor against myocardial infarction and stroke. JAMA 2004;291:2221-2228.

27 Paoletti R, Gotto AM Jr, Hajjar DP: Inflammation in atherosclerosis and implications for therapy. Circulation 2004;109(23 suppl 1):III20-III26.

28 Bertagnolli MM, Eagle CJ, Zauber AG, Redston M, Solomon SD, Kim K, Tang J, Rosenstein RB, Wittes J, Corle D, Hess TM, Woloj GM, Boisserie F, Anderson WF, Viner JL, Bagheri D, Burn J, Chung DC, Dewar T, Foley TR, Hoffman N, Macrae F, Pruitt RE, Saltzman JR, Salzberg B, Sylwestrowicz T, Gordon GB, Hawk ET, APC Study Investigators: Celecoxib for the prevention of sporadic colorectal adenomas. N Engl J Med 2006; 355:873-884.

29 Solomon SD, Pfeffer MA, McMurray JJ, Fowler R, Finn P, Levin B, Eagle C, Hawk E, Lechuga M, Zauber AG, Bertagnolli MM, Arber N, Wittes J, APC and PreSAP Trial Investigators: Effect of celecoxib on cardiovascular events and blood pressure in two trials for the prevention of colorectal adenomas. Circulation 2006;114:1028-1035.

30 McGettigan P, Henry D: Cardiovascular risk and inhibition of cyclooxygenase: a systematic review of the observational studies of selective and nonselective inhibitors of cyclooxygenase 2. JAMA 2006;296:1633-1644. 